\title{
Short Communication: \\ The Pattern of Heavy Metals Distribution in Time Chronosequence of Ex-Tin Mining Ponds in Bangka Regency, Indonesia
}

\author{
Andri Kurniawan ${ }^{1,2, *}$, Oedjijono ${ }^{2}$, Tamad $^{3}$, and Uyi Sulaeman ${ }^{4}$ \\ ${ }^{1}$ Department of Aquaculture, University of Bangka Belitung, \\ Jl. Balunijuk, Merawang, Bangka, Bangka Belitung 33172, Indonesia \\ ${ }^{2}$ Faculty of Biology, Jenderal Soedirman University, \\ Jl. Dr. Suparno no. 63, Karang Bawang, Grendeng, Purwokerto 53122, Central Java, Indonesia \\ ${ }^{3}$ Department of Agriculture, Jenderal Soedirman University, \\ Jl. Dr. Suparno no. 61, Karang Bawang, Grendeng, Purwokerto 53122, Central Java, Indonesia \\ ${ }^{4}$ Department of Chemistry, Faculty of Science and Technology, Jenderal Soedirman University, \\ Jl. Dr. Suparno no. 61, Karang Bawang, Grendeng, Purwokerto 53122, Central Java, Indonesia
}

\section{*Corresponding author:}

tel: $+62-81351714747$

email:andri-kurniawan@ubb.ac.id

Received: March 1, 2018

Accepted: July 17, 2018

DOI: $10.22146 /$ ijc.33613

\begin{abstract}
The heavy metals distribution of ex-tin mining ponds were investigated. The time chronosequence was determined at the pond of age $<1$ year (Station A), the pond of age 5-10 years (Station B), and the pond of age $>15$ years (Station $C$ ). The results showed sixteen heavy metals of $\mathrm{As}, \mathrm{Co}, \mathrm{Cu}, \mathrm{Cr}, \mathrm{Fe}, \mathrm{Ga}, \mathrm{Hf}, \mathrm{Sn}, \mathrm{Ta}, \mathrm{Te}, \mathrm{Th}, \mathrm{Mn}, \mathrm{Ni}, \mathrm{Pb}, \mathrm{Zn}$, and $\mathrm{V}$ could be detected in the ponds. The metals such as $\mathrm{As}, \mathrm{Co}, \mathrm{Cu}, \mathrm{Ga}, \mathrm{Mn}, \mathrm{Ni}, \mathrm{Pb}, \mathrm{Th}$, and $\mathrm{Zn}$ in Station $C$ showed higher concentration compared to the Station A and Station B. The metals such as $\mathrm{Cr}, \mathrm{Fe}, \mathrm{Hf}, \mathrm{Sn}, \mathrm{Ta}$, Te, and V in Station A and Station B showed higher concentration compared to the Station $C$. The positive, negative, and dynamic correlation pattern could be found in distribution of heavy metal to time chronosequence. The concentration of $\mathrm{Ta}$ and $V$ showed a positive correlation because their concentration decrease, whereas concentration of $\mathrm{As}, \mathrm{Cu}, \mathrm{Ga}, \mathrm{Mn}$, and $\mathrm{Zn}$ showed a negative correlation because their concentration increase along in time chronosequence. The dynamic correlation could be found that concentration of $\mathrm{Co}, \mathrm{Ni}, \mathrm{Pb}, \mathrm{Sn}$, and Th decrease from Station A to Station B and then increase in Station $C$, whereas concentration of $\mathrm{Cr}, \mathrm{Fe}$, $H f$, and Te increase from Station A to Station B and then decrease in Station C.
\end{abstract}

Keywords: distribution pattern; heavy metals; chronosequence; ex-tin mining ponds

\section{- INTRODUCTION}

Tin mining activity is an anthropogenic activity that has contributed to the ecological problems. It has been known as the major sources of heavy metal contamination such as heavy metals in ex-tin mining ponds. Ex-tin mining ponds as one of water resource were contaminated by heavy metals that can be accumulated in food chains and secondary activities of the water [1-3]. Some of the heavy metals such as $\mathrm{Pb}, \mathrm{Zn}, \mathrm{Mn}, \mathrm{Fe}, \mathrm{Cr}, \mathrm{Cu}$, $\mathrm{Ni}, \mathrm{Sn}, \mathrm{As}$, and $\mathrm{Cd}$ were detected in site of ex-tin mining [4-5].
The each of waters had their pattern of physical and chemical characteristics that determined by climatic, geomorphological, and geochemical conditions [6]. These conditions were influenced by ecological succession in time chronosequence [7] and the ecological changes of ex-tin mining ponds have occurred for a long time [8]. The implication of ecological changes as long as time chronosequence was interactions and reactions of chemical complexion between organic compounds, environmental factors, and inorganic compounds, include presence of heavy metals [9]. 
The researches of heavy metals in ex-tin mining ecosystems have been done, however, not for correspondence of heavy metals distributions and ex-tin mining ponds in time chronosequence. While an understanding this correspondence was crucial to predict ecosystems conditions and to detect environment change. The understanding of heavy metals distribution in time chronosequence of ex-tin mining ponds becomes an important part of aquatic ecosystem management as water sources for secondary activities and habitable for organisms.

\section{- EXPERIMENTAL SECTION}

\section{Materials}

The study areas were located in Bangka Regency, Bangka Belitung Archipelago Province of Indonesia. The considered study sites cover three ponds of ex-tin mining with chronosequence ranging in time. The study areas were encoded as Station A (pond in age $<1$ year), Station $\mathrm{B}$ (pond in age 5-10 years), and Station C (pond in age > 15 years).

The coordinate of Station A were $01^{\circ} 59^{\prime} \mathrm{S}$ in points 36.0 "; 36.2"; 36.4"; 36.5"; 36.6" and $106^{\circ} 06^{\prime} \mathrm{E}$ in points $36.5^{\prime \prime}$ 36.9"; 37.3"; 37.4"; 37.5". The coordinate of Station B were $01^{\circ} 59^{\prime} \mathrm{S}$ in points $41.3^{\prime \prime} ; 41.4^{\prime \prime} ; 41.5^{\prime \prime} ; 42.4^{\prime \prime} ; 42.5^{\prime \prime}$ and $106^{\circ} 06^{\prime} \mathrm{E}$ in points $39.2^{\prime \prime} ; 39.5^{\prime \prime} ; 41.4^{\prime \prime} ; 42.7^{\prime \prime} ; 43.1^{\prime \prime}$. The coordinate of Station C were $01^{\circ} 55^{\prime} \mathrm{S}$ in points $40.9^{\prime \prime} ; 58.9^{\prime \prime}$; $59.1^{\prime \prime}$ 59.2"; $59.5^{\prime \prime}$ and $106^{\circ} 06^{\prime} \mathrm{E}$ in points $19.5^{\prime \prime}$; $19.7^{\prime \prime}$; $19.9^{\prime \prime} ; 22.4^{\prime \prime} ; 29.2^{\prime \prime}$.

In the each of research stations points, water sampling was done $<4 \mathrm{~m}$ in depth (station code A.1; B.1; and C.1) and composite sampling were done to water and sediment $>4 \mathrm{~m}$ in depth (station code A.2; B.2; and C.2).

\section{Instrumentation}

The water samples and composite samples were analyzed $\mathrm{pH}$ value by $\mathrm{pH}$ meter (PH-009(I)-A) Sun Care. The speciation and concentration of heavy metals analyzed by X-Ray Fluorescence (Rigaku) with three light spreader metals of copper $(\mathrm{Cu})$, molybdenum $(\mathrm{Mo})$, and aluminum (Al). Also, the $\mathrm{pH}$ and moisture of soil around the ponds were measured by $\mathrm{pH}$-moisture meter. The correspondence between heavy metals distribution and the time chronosequence of ex-tin mining ponds was analyzed by PAST (Palaentological Statistics) 3.

\section{- RESULTS AND DISCUSSION}

\section{pH Value of Water and Soil}

Tin mining activity had generated the ex-tin mining ponds as one of the water resources. However, water quality in the ponds had serious ecological problem. The ex-mining activity produced acid mine drainage (AMD) that can caused the long-term impairment of water quality and biodiversity. The $\mathrm{pH}$ value of ex-tin mining water and soil $\mathrm{pH}$ value indicated that the acid could be found in Station A (pond in age $<$ 1 year) and Station $B$ (pond in age 5-10 years) and the neutral value could be found in Station C (pond in age $>$ 15 years). In the each of research stations points, water samples $<4 \mathrm{~m}$ in depth indicated more acid than the composite samples (water and sediment $>4 \mathrm{~m}$ in depth) (Fig. 1).

The acid mine drainage (AMD) was produced when sulfide-bearing material is exposed to oxygen and water [10]. In acid mine drainage, presence and mobility of elements such as $\mathrm{Al}, \mathrm{As}, \mathrm{Ca}, \mathrm{Cd}, \mathrm{Co}, \mathrm{Cr}, \mathrm{Cu}, \mathrm{Fe}, \mathrm{K}, \mathrm{Mg}$, $\mathrm{Mn}, \mathrm{Na}, \mathrm{Ni}, \mathrm{Pb}, \mathrm{Zn}$, and also ionic activity and sulphide

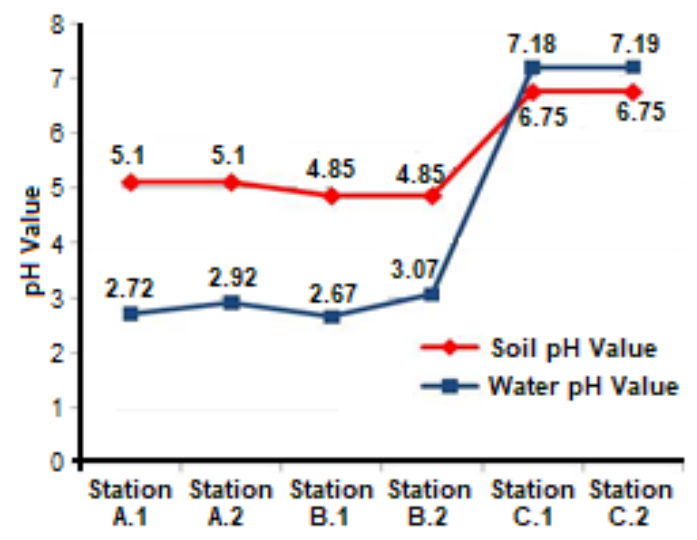

Fig 1. Soil and water $\mathrm{pH}$ value in time chronosequence of ex-tin mining ponds in Bangka Regency of Indonesia. The Station A (pond in age $<1$ year), Station B (pond in age $5-10$ years), and Station $C$ (pond in age $>15$ years). The station code (A.1, B.1, and C.1) showed water samples $<4 \mathrm{~m}$ in depth and the station code (A.2, B.2, and C.2) showed composite samples (water and sediment $>4 \mathrm{~m}$ in depth) 
minerals oxidation caused $\mathrm{pH}$ value decreasing [11-12]. Furthermore, the low $\mathrm{pH}$ condition implicated in oxidation state, toxicity, and mobility of elements [9].

In long time chronosequence more than 15 years in the Station $\mathrm{C}$ caused changes water quality of ex-tin mining ponds were more stable than Station $\mathrm{A}$ and Station B. The indicator for it was $\mathrm{pH}$ value increased to neutral conditions (7.0-7.4) and other parameters that indicated water quality was more habitable for organisms' life such as fishes. The $\mathrm{pH}$ value and other parameters changes, indirectly, caused ecological productivity increasing. The chronosequence in long time caused changes in nutrient availability and resource supply for ecosystem productivity [13].

The $\mathrm{pH}$ value was found to play the most important role in the determination of metal speciation, solubility from mineral surfaces, movement, and bioavailability of metals. Furthermore, acid mine drainage had a major contribution in heavy metal contamination [14]. There was a negative correlation between soil $\mathrm{pH}$ and distribution heavy metal where $\mathrm{pH}$ value decreasing caused increasing in heavy metal desorption [15].

\section{The Pattern of Heavy Metals Distribution}

The heavy metals that detected in ex-tin mining ponds were 16 element that $\mathrm{As}, \mathrm{Co}, \mathrm{Cu}, \mathrm{Cr}, \mathrm{Fe}, \mathrm{Ga}, \mathrm{Hf}$, $\mathrm{Sn}, \mathrm{Ta}, \mathrm{Te}, \mathrm{Th}, \mathrm{Mn}, \mathrm{Ni}, \mathrm{Pb}, \mathrm{Zn}$, and $\mathrm{V}$. All of these heavy metals were distributed in almost of research stations. Distribution of heavy metals can be grouped in low $\mathrm{pH}$ value or acid condition (in Station A and Station B) and neutral condition (in Station C) (Table 1).

There were nine heavy metals with higher concentration were found in Station $\mathrm{C}$ than Station A and Station $\mathrm{B}$ that $\mathrm{As}, \mathrm{Co}, \mathrm{Cu}, \mathrm{Ga}, \mathrm{Mn}, \mathrm{Ni}, \mathrm{Pb}$, Th, and $\mathrm{Zn}$. The average of As concentration were $1.7475 \mathrm{ppm}$ (Station C) $>1.6075 \mathrm{ppm}$ (Station B) > 1.0775 ppm (Station A). The concentration of Co were $3.32 \mathrm{ppm}$ (Station C) $>$ 2.525 ppm (Station A) > not detected (Station B). The concentration of $\mathrm{Cu}$ were $6.375 \mathrm{ppm}$ (Station C) > $5.4825 \mathrm{ppm}($ Station B) $>4.9775 \mathrm{ppm}$ (Station A).

Table 1. Distribution of heavy metals in time chronosequence in water of ex-tin mining ponds

\begin{tabular}{|c|c|c|c|c|c|c|c|}
\hline \multirow{3}{*}{ No } & \multirow{3}{*}{ Heavy Metals } & \multicolumn{6}{|c|}{ Heavy Metals Concentration (ppm) } \\
\hline & & \multicolumn{2}{|c|}{ In Station A } & \multicolumn{2}{|c|}{ In Station B } & \multicolumn{2}{|c|}{ In Station C } \\
\hline & & Station A.1 & Station A.2 & Station B.1 & Station B.2 & Station C.1 & Station C.2 \\
\hline 1 & As & nd & 2.155 & nd & 3.215 & 2.4 & 1.095 \\
\hline 2 & $\mathrm{Ga}$ & nd & 4.275 & nd & 4.47 & 9.76 & nd \\
\hline 3 & $\mathrm{~V}$ & nd & 0.84 & nd & nd & nd & 0.67 \\
\hline 4 & $\mathrm{Te}$ & nd & nd & 102 & nd & nd & 5.8 \\
\hline 5 & $\mathrm{Cr}$ & nd & 4.735 & nd & 4.945 & nd & 0.67 \\
\hline 6 & $\mathrm{Zn}$ & nd & 6.05 & nd & 8.1 & 8.17 & 3.905 \\
\hline 7 & $\mathrm{Sn}$ & 47 & 82.8 & 50.3 & 51.4 & 61.8 & 57.15 \\
\hline 8 & $\mathrm{Mn}$ & nd & 13.05 & nd & 13.6 & 30.8 & 14.85 \\
\hline 9 & $\mathrm{Fe}$ & 21.4 & 1481.3 & 148 & 2344 & 1590 & 849.05 \\
\hline 10 & Co & nd & 5.05 & nd & nd & 6.64 & nd \\
\hline 11 & $\mathrm{Ni}$ & nd & 4.09 & nd & 2.875 & 3.48 & 1.905 \\
\hline 12 & $\mathrm{Cu}$ & 3.08 & 6.875 & 3.19 & 7.775 & 8.94 & 3.81 \\
\hline 13 & $\mathrm{~Pb}$ & nd & 6.7 & nd & 6 & 8.21 & 4.62 \\
\hline 14 & Th & nd & 4.605 & nd & 4.38 & 13.5 & 7.05 \\
\hline 15 & $\mathrm{Hf}$ & 6.71 & 3.21 & 8.21 & 3.32 & nd & 9.38 \\
\hline 16 & $\mathrm{Ta}$ & 4.94 & 2.615 & 4.16 & 2.995 & nd & 2.805 \\
\hline
\end{tabular}

*) nd (not detected). The Station A (pond in age $<1$ year), Station B (pond in age 5-10 years), and Station C (pond in age $>15$ years). The station code (A.1, B.1, and C.1) showed water samples $<4 \mathrm{~m}$ in depth and the station code (A.2, B.2, and C.2) showed composite samples (water and sediment $>4 \mathrm{~m}$ in depth) 
The concentration of Ga were $4.88 \mathrm{ppm}$ (Station C) > $2.235 \mathrm{ppm}$ (Station B) $>2.1375 \mathrm{ppm}$ (Station A). The concentration of Mn were $22.825 \mathrm{ppm}$ (Station C) $>6.8 \mathrm{ppm}$ (Station B) $>6.525 \mathrm{ppm}$ (Station A). The concentration of Ni were $2.6925 \mathrm{ppm}$ (Station C) $>2.045 \mathrm{ppm}$ (Station A) $>1.4375 \mathrm{ppm}$ (Station $\mathrm{B}$ ). The concentration of $\mathrm{Pb}$ were $6.415 \mathrm{ppm}($ Station C) $>3.35 \mathrm{ppm}($ Station A) $>3.0 \mathrm{ppm}$ (Station B). The concentration of Th were $10.275 \mathrm{ppm}$ (Station C) $>2.3025 \mathrm{ppm}($ Station A) $>2.19 \mathrm{ppm}$ (Station B). The concentration of $\mathrm{Zn}$ were $6.0375 \mathrm{ppm}$ (Station C) $>4.05 \mathrm{ppm}$ (Station B) > $3.025 \mathrm{ppm}$ (Station A).

In addition, there were seven heavy metals with higher concentration in Station A or Station B than Station $\mathrm{C}$ that $\mathrm{Cr}, \mathrm{Fe}, \mathrm{Hf}, \mathrm{Sn}, \mathrm{Ta}, \mathrm{Te}$, and V. The average of $\mathrm{Cr}$ concentration were $2.4725 \mathrm{ppm}$ (Station B) > $2.3675 \mathrm{ppm}$ (Station A) > $0.335 \mathrm{ppm}$ (Station C). The concentration of $\mathrm{Fe}$ were $1246 \mathrm{ppm}$ (Station B) > 1219.53 ppm (Station C) $>751.35$ ppm (Station A). The concentration of Hf were 5.765 ppm (Station B) $>4.96 \mathrm{ppm}$
(Station A) > 4.69 ppm (Station C). The concentration of Sn were $64.9 \mathrm{ppm}$ (Station A) > $59.475 \mathrm{ppm}$ (Station C) $>50.85 \mathrm{ppm}$ (Station B). The concentration of Ta were $3.7775 \mathrm{ppm}$ (Station A) > $3.5775 \mathrm{ppm}$ (Station B) > 1.4025 ppm (Station C). The concentration of Te were $51 \mathrm{ppm}($ Station B $)>2.9 \mathrm{ppm}($ Station $\mathrm{C})>$ not detected (Station A). The concentration of $\mathrm{V}$ were $0.42 \mathrm{ppm}$ $($ Station A) $>0.335 \mathrm{ppm}($ Station $\mathrm{C})>$ not detected (Station B).

Their concentration of heavy metals in time chronosequence in ex-tin mining ponds showed three patterns distribution that a positive correlation, a negative correlation, and a dynamic correlation. The positive correlation indicated that concentration of heavy metals decreased along chronosequence in time in ex-tin mining ponds. The negative correlation indicated that concentration of heavy metals increased along chronosequence in time in ex-tin mining ponds. The dynamic correlation indicated that concentration of

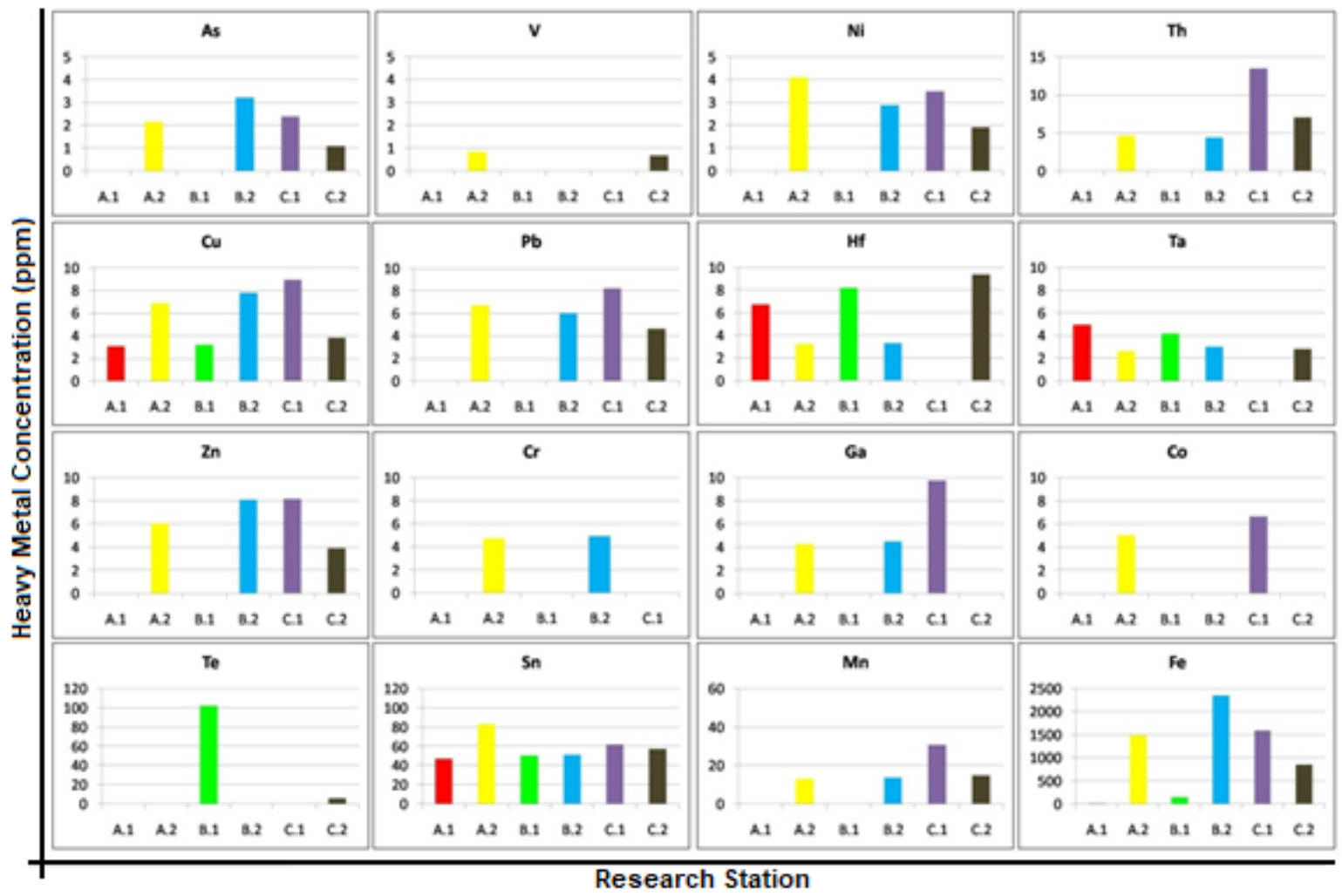

Fig 2. Distribution of heavy metals in time chronosequence of ex-tin mining ponds in Bangka Regency of Indonesia. The Station A (pond in age $<1$ year), Station B (pond in age 5-10 years), and Station C (pond in age $>15$ years). The station code (A.1, B.1, and C.1) showed water samples $<4 \mathrm{~m}$ in depth and the station code (A.2, B.2, and C.2) showed composite samples (water and sediment $>4 \mathrm{~m}$ in depth) 
heavy metals on decreased or increased along chronosequence in time in ex-tin mining ponds.

The elements of $\mathrm{Ta}$ and $\mathrm{V}$ had a positive correlation in time chronosequence in ex-mining ponds with their concentration on decreasing. The elements of $\mathrm{As}, \mathrm{Cu}, \mathrm{Ga}$, $\mathrm{Mn}$, and $\mathrm{Zn}$ had a negative correlation with their concentration on increasing along in time chronosequence. In addition, $\mathrm{Co}, \mathrm{Ni}, \mathrm{Pb}, \mathrm{Sn}$, and $\mathrm{Th}$ had decreased concentration from ponds with age $<1$ year to ponds with age between 5-10 years and then increased concentration in ponds with age $>15$ years. The elements of $\mathrm{Cr}, \mathrm{Fe}, \mathrm{Hf}$, and $\mathrm{Te}$ had increased concentration from ponds with age $<1$ year to ponds with age between 5-10 years and then decreased concentration in ponds with age $>15$ years (Fig. 2 ).

The chronosequence in long time caused changes in heavy metals concentration were decreased as the primary succession progression [16]. The low $\mathrm{pH}$ value implicated to dissolved oxygen (DO) [17] and low DO in acid mine drainage implicated to biological oxygen demand (BOD) by microorganisms for their growth and other ecological factor changes such as nitrogen and phosphate [7,18-19]. Nitrogen (ammonia, nitrite, and nitrate) and phosphate were important for sustenance of various life forms, primary succession, and led to changes in the biogeochemical cycles of nutrients in ponds [20-22], indirectly implicated to dissolved and suspended solid [23-24] and ecosystem eutrophic levels [25-31]. Therefore, $\mathrm{pH}$ value changes, availability of elements included heavy metals, environmental characteristics, and eutrophication had a positive inter-relationships in their correspondence.

These conditions, however, had a negative correlation to heavy metals residue decreasing in Station C. The heavy metals in Station C were dominated As, Zn, $\mathrm{Mn}, \mathrm{Co}, \mathrm{Ni}, \mathrm{Cu}, \mathrm{Pb}$, and Th were higher than Station $\mathrm{A}$ and Station B, although these metals and include $\mathrm{Ga}, \mathrm{Cr}$, $\mathrm{Sn}, \mathrm{Fe}, \mathrm{Hf}$, and Ta were detected in all of the research station. The results indicated that chronosequence in time of ponds caused ecological changes and had positive correlations, but not for distribution of heavy metals.

\section{The Correspondence Analysis of Heavy Metals Distribution}

The correspondence analysis also showed that there was not a positive correlation between in time chronosequence in water of ex-tin mining ponds and

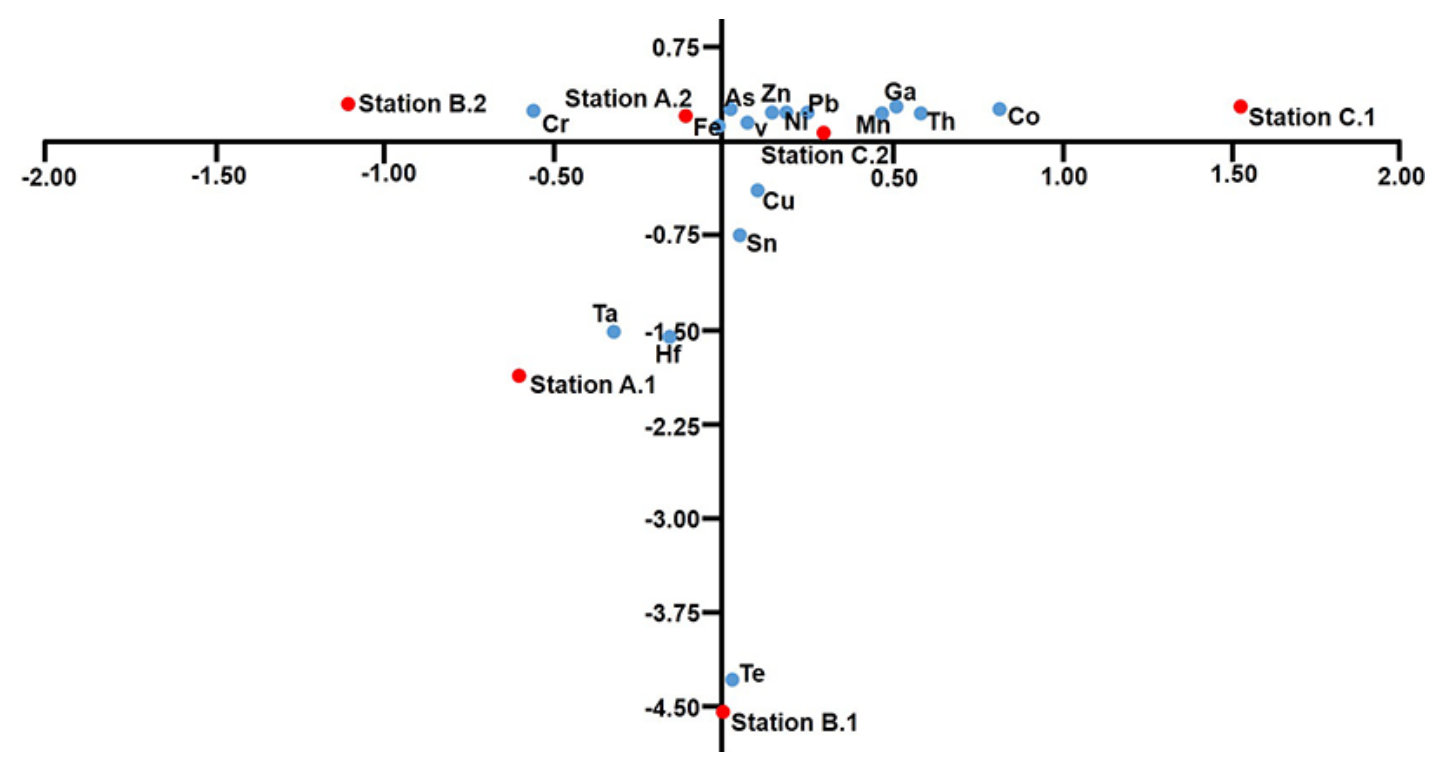

Fig 3. Correspondence analysis between distribution of heavy metals and in time chronosequence of ex-tin mining ponds in Bangka Regency of Indonesia. The Station A (pond in age < 1 year), Station B (pond in age 5-10 years), and Station C (pond in age $>15$ years). The station code (A.1, B.1, and C.1) showed water samples $<4 \mathrm{~m}$ in depth and the station code (A.2, B.2, and C.2) showed composite samples (water and sediment $>4 \mathrm{~m}$ in depth) 
heavy metals distribution (Fig. 3). The ecological changes in chronosequence succession of ex-tin mining ponds had not significantly affect on speciation and concentration of heavy metals. Thus, there was the other factor that had affected the distribution of heavy metals.

The soil and sediment of water contributed to the distribution of heavy metals [32]. In general, the mobility and availability of heavy metals were controlled by adsorption and desorption characteristics of soils, include cation exchange capacity and the contents of clay minerals [15]. The clay and mud were found to be dominant in the sediment of Station A and Station B, however, sand was found to be dominant in Station C.

The clay and mud had a positive correlation and sand had a negative correlation to a presence, affinity, and minerals structure [33-34]. The clay and mud had a larger surface area, higher cation exchange capability (CEC), and particles of clay in sediments were often closely associated with organic matter and also exist in the form of organic-mineral complexes. These particles adsorbed the active metals from the water phases, accumulated, and carried them to the bottom sediments diagenetically [3536]. Therefore, distribution of heavy metals in Station $A$ and Station B were lower than Station C.

\section{- CONCLUSION}

In time chronosequence of ex-tin mining ponds had affected ecological dynamic such as $\mathrm{pH}$ value change and heavy metals distribution. The $\mathrm{pH}$ value of ex-tin mining ponds moved from acid to neutral condition, however, it had been taken for a long time of the chronosequence. The consequence of low $\mathrm{pH}$ value can implicated to microorganisms' growth, nutrients, and environment factors in primary succession. Further, it implicated to heavy metals interaction, whereas the heavy metals residue should be in low concentration in long time chronosequence of ex-tin mining ponds.

The heavy metals that detected in ex-tin mining ponds were 16 element that $\mathrm{As}, \mathrm{Co}, \mathrm{Cu}, \mathrm{Cr}, \mathrm{Fe}, \mathrm{Ga}, \mathrm{Hf}, \mathrm{Sn}$, $\mathrm{Ta}, \mathrm{Te}, \mathrm{Th}, \mathrm{Mn}, \mathrm{Ni}, \mathrm{Pb}, \mathrm{Zn}$, and V. All of these heavy metals were distributed in almost of research stations. Distribution of heavy metals can be grouped in low $\mathrm{pH}$ value or acid condition (in Station A and Station B) and neutral condition (in Station C). There were nine heavy metals with higher concentration were found in Station $\mathrm{C}$ than Station A and Station B that As, Co, Cu, Ga, Mn, $\mathrm{Ni}, \mathrm{Pb}, \mathrm{Th}$, and $\mathrm{Zn}$. In addition, there were seven heavy metals with higher concentration in Station A or Station B than Station C that Cr, Fe, Hf, Sn, Ta, Te, and V.

There were three patterns of heavy metals distribution in time chronosequence in ex-tin mining ponds that a positive correlation, a negative correlation, and a dynamic correlation. The chronosequence in time had affects on heavy metals distribution. Elements of Ta and $\mathrm{V}$ had a positive correlation in time chronosequence in ex-mining ponds with their concentration on decreasing. Elements of $\mathrm{As}, \mathrm{Cu}, \mathrm{Ga}, \mathrm{Mn}$, and $\mathrm{Zn}$ had a negative correlation with their concentration on increased along in time chronosequence. In addition, $\mathrm{Co}, \mathrm{Ni}, \mathrm{Pb}, \mathrm{Sn}$, and $\mathrm{Th}$ had decreased concentration from ponds with age $<1$ year to ponds with age between 5-10 years and then increased concentration in ponds with age $>15$ years. Elements of $\mathrm{Cr}, \mathrm{Fe}, \mathrm{Hf}$, and Te had increased concentration from ponds with age $<1$ year to ponds with age between 5-10 years and then decreased concentration in ponds with age $>15$ years.

The chronosequence in time can be a factor that contributed to heavy metals distribution. However, the sediment factor had a significant effect to distribution of heavy metals in the ex-tin mining ponds, where clay and mud were more effective than sand in accumulation, adsorption, and interaction with heavy metals and carried them diagenetically to bottom sediments.

\section{- ACKNOWLEDGMENTS}

I would like to thank Ministry of Research, Technology and Higher Education of the Republic of Indonesia for scholarship of Pendidikan Pascasarjana Dalam Negeri (BPPDN) and research grant of Program Disertasi Doktor (PDD) for the funding with Project No: 120.G/UN50.3.1/PP/2018.

\section{- REFERENCES}

[1] de Silva, A.A.L., de Carvalho, M.A.R., de Souza, S.A.L., Dias, P.M.T., Filho, R.G.S., Saramago, C.S.M., Bento, C.A.M., and Hofer, E., 2012, Heavy 
metal tolerance (Cr, $\mathrm{Ag}$ and $\mathrm{Hg}$ ) in bacteria isolated from sewage, Braz. J. Microbiol., 43 (4), 1620-1631.

[2] Guan, Y., Shao, C., and Ju, M., 2014, Heavy metal contamination assessment and partition for industrial and mining gathering areas, Int. J. Environ. Res. Public Health, 11 (7), 7286-7303.

[3] Kurniawan, A., 2017, Chronosequence effect of post tin mining ponds to metals residu and micro ecosystem change, Omni-Akuatika, 13 (1), 60-65.

[4] Ashraf, M.A., Maah, M.J., and Yusoff, I., 2012, Speciation of heavy metals in the sediments of former tin mining catchment, Iran. J. Sci. Technol. Trans. A Sci., 36 (2), 163-180.

[5] Daniel, V.N., Chudusu, E.S., Chup, J.A., and Pius, N.D., 2014, Variations of heavy metals in agricultural soils irrigated with tin water in Heipang District of Barkin Ladi, Plateau State, Nigeria, Int. J. Sci. Technol., 3 (5), 255-263.

[6] Ashraf, M.A., Maah, M.J., and Yusoff, I., 2012, Morphology, geology and water quality assessment of former tin mining catchment, Sci. World J., 2012, 369206.

[7] Urbanová, M., Kopecký, J., Valášková, V., SágováMarečková, M., Elhottová, D., Kyselková, M., Moënne-Loccoz, Y., and Baldrian, P., 2011, Development of bacterial community during spontaneous succession on spoil heaps after brown coal mining, FEMS Microbiol. Ecol., 78 (1), 59-69.

[8] Kurniawan, A., 2016, Microorganism communities response of ecological changes in post tin mining ponds, RRJoMV, 6 (1), 17-26.

[9] Violante, A., Cozzolino, V., Perelomov, L., Caporale, A.G., and Pigna, M., 2010, Mobility and bioavailability of heavy metals and metalloids in soil environments, J. Soil Sci. Plant Nutr., 10 (3), 268-292.

[10] Akcil, A., and Koldas, S., 2006, Acid mine drainage (AMD): causes, treatment and case studies, J. Cleaner Prod., 14 (12-13), 1139-1145.

[11] Tan, G.L., Shu, W.S., Hallberg, K.B., Li, F., Lan, C.Y., and Huang, L.N., 2007, Cultivation-dependent and cultivation-independent characterization of the microbial community in acid mine drainage associated with acidic $\mathrm{Pb} / \mathrm{Zn}$ mine tailings at
Lechang, Guangdong, China, FEMS Microbiol. Ecol., 59 (1), 118-126.

[12] Campaner, V.P., Luiz-Silva, W., and Machado, W., 2014, Geochemistry of acid mine drainage from a coal mining area and processes controlling metal attenuation in stream waters, Southern Brazil, $A n$. Acad. Bras. Ciênc., 86 (2), 539-554.

[13] Bardgett, R.D., Bowman, W.D., Kaufmann, R., and Schmidt, S.K., 2005, A temporal approach to linking aboveground and belowground ecology, Trends Ecol. Evol., 20 (11), 634-641.

[14] Ahmad, A.K., and Al-Mahaqeri, S.A., 2015, Human health risk assessment of heavy metals in fish species collected from catchments of former tin mining, Int. J. Res. Stud. Sci. Eng. Technol., 2 (4), 9-21.

[15] Zeng, F., Ali, S., Zhang, H., Ouyang, Y., Qiu, B., Wu, F., and Zhang, G., 2011, The influence of $\mathrm{pH}$ and organic matter content in paddy soil on heavy metal availability and their uptake by rice plants, Environ. Pollut., 159 (1), 84-91.

[16] Huang, L.N., Tang, F.Z., Song, Y.S., Wan, C.Y., Wang, S.L., Liu, W.Q., and Shu, W.S., 2010, Biodiversity, abundance, and activity of nitrogenfixing bacteria during primary succession on a copper mine tailings, FEMS Microbiol. Ecol., 78 (3), 439-450.

[17] Abdel-Raouf, N., Al-Homaidan, A.A., and Ibraheem, I.B.M., 2012, Microalgae and wastewater treatment, Saudi J. Biol. Sci., 19 (3), 257-275.

[18] Tscherko, D., Hammesfahr, U., Zeltner, G., Kandeler, E., and Böcker, R., 2005, Plant succession and rhizosphere microbial communities in a recently deglaciated alpine terrain, Basic Appl. Ecol., 6 (4), 367-383.

[19] Fierer, N., Nemergut, D., Knight, R., and Craine, J.M., 2010, Changes through time: Integrating microorganisms into the study of succession, Res. Microbiol., 161 (8), 635-642.

[20] Quirós, R., 2003, The relationship between nitrate and ammonia concentrations in the pelagic zone of lakes, Limnetica, 22 (1-2), 37-50.

[21] Michalski, R., and Kurzyca, I., 2006, Determination of nitrogen species (nitrate, nitrite and ammonia 
ions) in environmental samples by ion chromatography, Pol. J. Environ. Stud., 15 (1), 5-18.

[22] Mihale, M.J., 2015, Nitrogen and phosphorus dynamics in the waters of the Great Ruaha River, Tanzania, J. Water Resour. Ocean Sci., 4 (5), 59-71.

[23] Akan, J.C., Audu, S.I., Mohammed, Z., and Ogugbuaja, V.O., 2013, Assessment of heavy metals, $\mathrm{pH}$, organic matter and organic carbon in roadside soils in Makurdi Metropolis, Benue State, Nigeria, J. Environ. Prot., 4 (6), 618-628.

[24] Kuriata-Potasznik, A., Szymczyk, S., Skwierawski, A., Glińska-Lewczuk, K., and Cymes, I., 2016, Heavy metal contamination in the surface layer of bottom sediments in a flow-through lake: A case study of Lake Symsar in Northern Poland, Water, 8 (8), 358.

[25] Maher, W., Krikowa, F., Wruck, D., Louie, H., Nguyen, T., and Huang, W.Y., 2002, Determination of total phosphorus and nitrogen in turbid waters by oxidation with alkaline potassium peroxodisulfate and low pressure microwave digestion, autoclave heating or the use of closed vessels in a hot water bath: Comparison with Kjeldahl digestion, Anal. Chim. Acta, 463 (2), 283-293.

[26] Song, Y., Hahn, H.H., and Hoffmann, E., 2002, Effects of solution conditions on the precipitation of phosphate for recovery a thermodynamic evaluation, Chemosphere, 48 (10), 1029-1034.

[27] Kumar, M.M.S.Y., Galil, M.S.A., Suresha, M.S., Sathish, M.A., and Nagendrappa, G., 2007, A simple spectrophotometric determination of phosphate in sugarcane juices, water, and detergent samples, E-J. Chem., 4 (4), 467-473.

[28] Topçu, A., and Pulatsü, S., 2014, Phosphorus fractions and cycling in the sediment of a shallow eutrophic pond, J. Agric. Sci., 20 (1), 63-70.
[29] Sengupta, S., Nawaz, T., and Beaudry, J., 2015, Nitrogen and phosphorus recovery from wastewater, Curr. Pollut. Rep., 1 (3), 155-166.

[30] Cerozi, B.S., and Fitzsimmons, K., 2016, The effect of $\mathrm{pH}$ on phosphorus availability and speciation in an aquaponics nutrient solution, Bioresour. Technol., 219, 778-781.

[31] Lei, Y., Song, B., van der Weijden, R.D., Saakes, M., and Buisman, C.J.N., 2017, Electrochemical induced calcium phosphate precipitation: importance of local pH, Environ. Sci. Technol., 51 (19), 11156-11164.

[32] De Saedeleer, V., Cappuyns, V., De Cooman, W., and Swennen, R., 2010, Influence of major elements on heavy metal composition of river sediments, Geol. Belg., 13 (3), 257-268.

[33] Jiang, M., Zeng, G., Zhang, C., Ma, X., Chen, M., Zhang, J., Lu, L., Yu, Q., Hu, L., and Liu, L., 2012, Assessment of heavy metal contamination in the surrounding soils and surface sediments in Xiawangang River, Qingshuitang District, PLoS One, 8 (8), e71176.

[34] Alamgir, M., Islam, M., Hossain, N., Kibria, M.G., and Rahman, M.M., 2015, Assessment of heavy metal contamination in urban soils of Chittagong City, Bangladesh, Int. J. Plant Soil Sci., 7 (6), 362-372.

[35] Zhang, C., Yu, Z., Zeng, G., Jiang, M., Yang, Z., Cui, F., Zhu, M., Shen, L., and Hu, L., 2014, Effects of sediment geochemical properties on heavy metal bioavailability, Environ. Int., 73, 270-281.

[36] Yao, Q., Wang, X., Jian, H., Chen, H., and Yu, Z., 2015, Characterization of the articles size fraction associated with heavy metals in suspended sediments of the Yellow River, Int. J. Environ. Res. Public Health, 12 (6), 6725-6744. 